Економічні науки: збірник наукових праць Луцького національного технічного університету. - Серія "Регіональна економіка". - Випуск 15 (59). - Редкол.: відп. ред. д.е.н., професор Л.Л. Ковальська. - Луцьк: ІВВ Луцького НТУ, 2018. - 292 с.

УДК 630.2(477.87)

Лендєл М.А., Газуда С.М.

Ужгородський торговельно-економічний інститут КНТЕУ

\title{
РЕГІОНАЛЬНІ ЗАСАДИ РАЦІОНАЛЬНОГО ЛІСОГОСПОДАРЮВАННЯ
}

Розглянуто основні засади раціонального лісогосподарювання та лісокористування в лісовій сфері регіону. На основі узагальнення результатів досліджень і наукових публікацій сформовано і обгрунтовано основні напрями раціонального ведення лісового господарства 3 метою забезпечення збалансованого i сталого розвитку лісогосподарського комплексу транскордонного регіону.

Ключові слова: лісогосподарювання, лісокористування, соціальноекономічний розвиток.

\section{Lendel M., Gazuda S.}

\section{REGIONAL PRINCIPLES FOR RATIONAL FOREST MANAGEMENT}

The basic principles of rational forest management and forest use in the forest area of the region have been considered. On the basis of the generalization of research results and scientific publications, the main directions of rational management of forestry have been formulated and grounded in order to ensure 
Економічні науки: збірник наукових праць Луцького національного технічного університету. - Серія "Регіональна економіка". - Випуск 15 (59). - Редкол.: відп. ред. д.е.н., професор Л.Л. Ковальська. - Луиьк: ІВВ Луиького НТУ, 2018. - 292 с.

balanced and sustainable development of the forestry complex of the transboundary region.

Key words: forest management, forest management, socio-economic development.

Лендєл М., Газуда С.

\section{РЕГИОНАЛЬНЫЕ ОСНОВЫ РАЦИОНАЛЬНОГО ЛЕСОХОЗЯЙСТВОВАНИЯ}

Рассмотрены основные принципы рационального лесохозяйствования и лесопользования в лесной сфере региона. На основе обобщения результатов исследований и научных публикаций сформирован и обоснованы основные направления рационального ведения лесного хозяйства с целью обеспечения сбалансированного и устойчивого развития лесного комплекса трансграничного региона.

Ключевые слова: лесохозяйствования, лесопользования, социальноэкономическое развитие.

\section{Постановка проблеми у загальному вигляді і її зв'язок} 3 важливими науковими та практичними завданнями. Вирішення проблем лісового господарства i галузей деревообробної промисловості $є$ особливо актуальними для функціонування економіки Закарпаття. Серед стратегічних цілей соціально орієнтованої ринкової економіки, як зазначено у „Стратегіï економічного та соціального розвитку Закарпатської області до 2020 року" пріоритетним визнано розвиток лісопромислового виробництва. Постає завдання розроблення та впровадження інноваційних продуктів i технологій у вищеназвану галузь регіону, і зокрема, залучення новітніх прогресивних технологій ведення діяльності у сфері лісового господарства та деревообробної промисловості.

Аналіз останніх досліджень, у яких започатковано вирішення проблеми. Теоретичним дослідженням проблемних питань раціонального лісогосподарювання i забезпечення охорони навколишнього природного середовища присвятили свої праці вітчизняні вчені Р. Бабич, О. Дзюбенко [1]; М. Бойко [2]; В. Голян [3]; Я. Коваль [4]; Б. Колісник [5]; М. Хвесик, О. Шубалий, Н. Василик [6] та ін. Однак, незважаючи на багатогранне висвітлення наукових підходів до формування 
Економічні науки: збірник наукових праць Луцького національного технічного університету. - Серія "Регіональна економіка". - Випуск 15 (59). - Редкол.: відп. ред. д.е.н., професор Л.Л. Ковальська. - Луцьк: ІВВ Луцького НТУ, 2018. - 292 с.

збалансованого розвитку сфери природокористування, додаткових досліджень потребують регіональні проблеми забезпечення раціонального лісокористування у процесі лісогосподарської діяльності.

Цілі дослідження. Основна мета дослідження полягає у розробці напрямів підвищення ефективності раціонального лісокористування у регіонах держави.

Виклад основного матеріалу дослідження 3 повним обгрунтуванням отриманих наукових результатів. Гірська місцевість Закарпаття майже на всій своїй території вкрита лісами, лісистість території області найвища в Україні, загальна площа лісового фонду Закарпатської області 694 тис. га, що становить 51\% до загальної кількості лісів держави. Ліси Закарпаття виконують дуже багато функцій, більшість 3 яких захисного, екологічного характеру, основними 3 яких $\epsilon$ водорегулювання, захист басейнів річок від повені, ерозії грунтів та рекреація.

За розрахунками спеціалістів кореневий запас у лісовому фонді області - понад 230 млн. м³. Середній запас на 1 га вкритих лісовою рослинністю земель становить 334 кубометри, a в окремих деревостанах такий запас може сягати тисячі кубометрів. Щорічно приростає в середньому 5 кубометрів деревини на один гектар.

За п'ять останніх років рубки лісу головного користування становили щорічно в середньому 438 тис. ${ }^{3}$ ліквідної деревини, а внаслідок рубок, пов'язаних 3 веденням лісового господарства 938 тис. м $^{3}$ або в сумі 38,8 \% щорічного приросту деревної маси.

У лісовому господарстві Закарпатської області у 2010 р. було зайнято 47,8 тис. працівників або 9,2\% економічно активного населення. Отже, лісокористування i ведення лісового господарства $є$ основним видом господарської діяльності та джерелом доходу для значної частини жителів регіону. Тому, ефективне використання лісів та лісосировинних ресурсів $\epsilon$ одним 3 визначальних факторів сталого 
Економічні науки: збірник наукових праць Луцького національного технічного університету. - Серія "Регіональна економіка". - Випуск 15 (59). - Редкол.: відп. ред. д.е.н., професор Л.Л. Ковальська. - Луцьк: ІВВ Луцького НТУ, 2018. - 292 с.

економічного розвитку області та життєзабезпечення населення [1, с. 20-24].

Слід однак зазначити, що в післявоєнні десятиліття в лісах області велися безсистемні рубки, нарощувалися обсяги заготівлі деревини в межах до 2 млн. м щороку, в основному на придорожніх лісосіках. Навіть у 1965 р., на 20 році возз'єднання Закарпаття 3 Україною було заготовлено i вивезено 1892 тис. куб.м ділової деревини [2, с. 28].

Статистичні показники господарювання засвідчують, що в останні роки лісівники області більш раціонально ведуть лісове господарство. Якщо у 2015 р. обсяги заготівлі деревини від усіх видів рубок в області становили 1 млн. 402,6 тис. м $^{3}$, то у 2017 р. деревини було заготовлено 1 млн. 204,1 тис. м². Порівняно з 2015 р. рубалося на 200 тис. м , або на $15 \%$ менше. При цьому, надходження до бюджету від діяльності лісівників зросли. Так, якщо у 2015 р. обласним управлінням лісомисливського господарства було надано робіт та послуг на 616,8 млн. грн, то у 2016 р. цей показник зріс до 761,9 млн. грн, а у 2017 р. - до 887,9 млн. грн [3, с. 312].

Донедавна для бізнесових структур Закарпаття характерною ознакою було контрабандне вивезення за кордон необроблених лісоматеріалів. У цьому контексті своєчасним $є$ ухвалений Верховною Радою закон № 5495, який передбачає підвищення відповідальності за незаконне вивезення з України лісу і лісоматеріалів.

У Кримінальному кодексі України буде нова стаття № 201-1 про незаконне вивезення лісоматеріалів (зокрема необроблених), пиломатеріалів цінних та рідкісних порід дерев. Контрабанда всіх цих товарів передбачатиме відповідальність у вигляді позбавлення волі від 3 до 5 років. Якщо людина скоїла такий злочин не вперше або у великому розмірі - їй загрожуватиме позбавлення волі від 5 до 10 років, конфіскація майна і позбавлення права обіймати певні посади до 3 років.

Оновлена стаття передбачає покарання не тільки за рубку лісу, а й за незаконне перевезення, зберігання або збут лісу. Закон також передбачає збільшення штрафів за пошкодження 
Економічні науки: збірник наукових праць Луцького національного технічного університету. - Серія "Регіональна економіка". - Випуск 15 (59). - Редкол.: відп. ред. д.е.н., професор Л.Л. Ковальська. - Луцьк: ІВВ Луцького НТУ, 2018. - 292 с.

лісів. Документ набуде чинності з 1 січня 2019 р. На 8 років 3 набрання чинності законопроекту забороняється експорт паливної деревини. Безумовно, ухвалений закон про збереження українських лісів та запобігання незаконному вивезенню необроблених лісоматеріалів є важливим для Закарпаття адже дозволить зберегти ліси, раціонально вести лісове господарство, а місцевим лісопереробним підприємствам розвиватися, створювати робочі місця, мати необхідну кількість сировини та наповнювати податками місцеві бюджети.

У системі ведення лісогосподарської діяльності в області існує ряд проблем [4, с. 290]:

- посилилася проблема недостатнього платоспроможного попиту споживачів лісопродукції;

- незадовільна матеріально-технічна база, високий та середній ступінь зношеності засобів виробництва;

- невідповідний рівень державної підтримки господарських суб'єктів галузі для ефективного ведення лісогосподарювання;

- проблема плинності кадрів, недостатнє сприяння в підготовці і перепідготовці кадрів та обміні досвідом;

- слабкі коопераційні зв'язки між виробниками готової продукції 3 деревини в межах області для продажу ii y перспективі за кордон;

- в умовах жорсткої конкуренції підприємств лісової галузі на зовнішньому ринку відсутність належного рівня законодавчого регулювання участі лісогосподарських підприємств у зовнішньоекономічній діяльності.

На основі узагальнення результатів досліджень і наукових публікацій, в тому числі і авторських, стає можливим окреслити i теоретично обгрунтувати основні напрями забезпечення раціонального ведення лісового господарства та лісокористування, ефективного функціонування та збалансованого розвитку лісогосподарського комплексу транскордонного регіону. 
Економічні науки: збірник наукових праць Луцького національного технічного університету. - Серія "Регіональна економіка". - Випуск 15 (59). - Редкол.: відп. ред. д.е.н., професор Л.Л. Ковальська. - Луцьк: ІВВ Луцького НТУ, 2018. - 292 с.

Основні ознаки забезпечення регіонального раціонального ведення лісового господарства та лісокористування такі:

- утвердження визнання престижності лісогосподарської сфери в системі господарського комплексу транскордонного регіону, визначення місця лісоресурсної сфери в системі еколого-економічного розвитку області;

- дотримання вимог законів і законодавчих актів щодо відтворення, охорони i використання лісових ресурсів, організаційно-правове забезпечення стимулювання комплексного використання лісоресурсного потенціалу, підвищення рівня відповідальності за дотримання лісового та природоохоронного законодавства;

- реалізація основних положень, організація лісовпорядкування, дотримання вимог державного лісового кадастру, обліку лісів;

- розроблення регіонального механізму комплексного використання лісоресурсного потенціалу на основі поєднання важелів та інструментів економічного стимулювання, використання функціональних принципів адміністративнорегуляторної, інноваційно-інвестиційної, фінансово-кредитної та організаційно-правової політики 3 метою отримання максимального еколого-економічного ефекту в галузях лісоресурсної сфери;

- забезпечення, збереження букових пралісів, зокрема, на заповідних територіях області, які сформувалися на 146,0 га;

- реформування наявної власності на землі лісогосподарського призначення, що передбачає: роздержавлення і приватизацію частки земель лісового фонду і лісових ресурсів, удосконалення системи лісогосподарського виробництва та системи управління лісами і лісогосподарською діяльністю;

- відновлення і випереджаюче зростання прогресивних виробництв, передусім деревних плит, паркету, картону, фанери, тароматеріалів, відродження меблевого виробництва та іншої продукції, що користується підвищеним попитом і 
Економічні науки: збірник наукових праць Луцького національного технічного університету. - Серія "Регіональна економіка". - Випуск 15 (59). - Редкол.: відп. ред. д.е.н., професор Л.Л. Ковальська. - Луцьк: ІВВ Луцького НТУ, 2018. - 292 с.

найбільш повно задовольняє потреби споживачів і вимог ринку і для економіки Закарпатської області є пріоритетом розвитку лісоресурсного комплексу і галузі в цілому;

- організація належної системи моніторингу господарювання в лісоресурсній сфері, систематичного здійснення аналізу економічних показників діяльності лісового комплексу, реалізація стратегічних пріоритетів подальшого зростання, що є актуальним для розвитку регіону;

- здійснення спеціалістами SWOT-аналізу стану розвитку лісового комплексу з метою оцінювання еколого-економічних втрат лісоресурсної сфери від природних чинників i антропогенного навантаження;

- удосконалення рентних лісоресурсних відносин, поглиблення методологічних засад економічної оцінки лісових ресурсів;

- поступове нарощування лісопромислового виробництва, підвищення його ефективності на основі удосконалення структури, інтенсифікації і зростання виробничого потенціалу, комплексного раціонального лісокористування на перспективу;

- ведення лісового господарства Закарпаття на основі реструктуризації виробничої і соціальної інфраструктур галузі в умовах утвердження ринкових відносин, реалізація рекомендацій спільного швейцарсько-українського проекту „Forza” з метою розвитку і посилення багатофункціонального ведення лісового господарства області, використання засобів наближеного до природи лісівництва та раціональної лісозаготівлі для підтримання функцій лісу i збільшення виробництва лісових товарів і послуг.

Результатом реалізації зазначених заходів стане запровадження життєздатних економічних i ринковоорієнтованих підходів та належних економічних методик у веденні лісового господарства та захисті ландшафту.

Висновки. Реалізація вищевикладених пріоритетних напрямів підвищення ефективності раціонального і розумного ведення лісового господарства і лісокористування, у поєднанні 3 засадами охорони навколишнього природного середовища 
Економічні науки: збірник наукових праџь Луцького національного технічного університету. - Серія "Регіональна економіка". - Випуск 15 (59). - Редкол.: відп. ред. д.е.н., професор Л.Л. Ковальська. - Луиьк: ІВВ Луиького НТУ, 2018. - 292 с.

сприятиме утвердженню сталого, екологічно збалансованого i безпечного розвитку лісопромислового комплексу, слугуватиме збереженню біосфери, різноманіття природних, соціальних та виробничих умов господарювання, забезпечить сталий соціально-економічний розвиток регіону.

1. Лендєл М.А., Рубіш М.А. Реалізація швейцарсько-українського проекту „Forza” - важливий фактор розвитку лісового господарства гірських територій Закарпаття// Науковий вісник Ужгородського національного університету. Вип. 35. Ч. 2. С. 20-24. Серія „Економіка”.

2. Народне господарство Закарпатської області. Ювілейний статистичний збірник. Карпати, 1975. С. 28.

3. Статистичний щорічник Закарпаття за 2016 р./Головне управління статистики у Закарпатській області; за ред. Г.Д. Гриник. Ужгород, 2017. 479 с.

4. Цалан М.І. Оцінка розвитку лісогосподарських підприємств Закарпатської області//Розвиток національної економіки: теорія і практика. Матеріали Міжнародної науково-практичної конференції 3-4 квітня 2015 р. Ч. 2. М. Івано-Франківськ, 2015. С. 290.

5. Бабич Р.Б., Дзюбенко О.М. Ліси Карпат - важлива складова еколого-економічної безпеки регіону/Сталий розвиток Карпат: сучасний стан та стратегія дій. Тези доповідей міжнар. наук.-практ. конф.//редкол.: відп. ред. В.С. Кравців. Львів: І-нт регіональних досліджень НАН України, 2006. C. $68-71$.

6. Бойко М. Сучасний маркетинговий підхід до комплексного використання лісових ресурсів/ М.М.Бойко//Науковий вісник Ужгородського національного університету. Серія «Економіка». - 2009. -Вип. 28, Ч. 1. C. 29-36.

7. Голян В.А Напрями вирішення проблем лісокористування / В.А. Голян, О.М. Шубалий// Економіка і держава. Міжнародний науковопрактичний журнал. - 2006. - № 11. - С. 44-47.

8. Коваль Я.В. Формування ринково-орієнтованого економічного механізму в лісоресурсній сфері/ Сталий розвиток Карпат: сучасний стан та стратегія дій. Тези доповідей міжнар. наук.-практ. конф.//редкол.: відп. ред. В.С. Кравців. Львів: І-нт регіональних досліджень НАН України, 2006. 196 с.

9. Колісник Б.І., Шубалий О.М. Еколого-економічна ефекивність регіонального лісогосподарського комплексу (проблеми та шляхи підвищення): Монографія. Фенікс, 2008. - 168 с.

10. Хвесик М.А., Шубалий О.М., Василик Н.М. Комплексне використання лісоресурсного потенціалу: механізм стимулювання інституціональне та інноваційно-інвестиційне забезпечення: монографія. Київ: ТОВ „ДКС”, 2011. 498 с. 